the aluminium can top, a lateral chest radiograph in which the foreign object is projected away from the spine, could be of some diagnostic value. Upper gastrointestinal endoscopy, with or without a flexible fibrescope, should be considered in every case of unexplained swallowing difficulty, even if the contrast study fails to show an abnormality.

A plea is made to manufacturers of metal cans either to incorporate a distinctive radio-opaque marker on the pull-ring, or to ensure that it cannot easily be detached from the can.

We thank Dr M H Wansbrough-Jones for referring the first case to us for surgical treatment from St George's Hospital, London.

\section{References}

1 Spitz L. Management of ingested foreign bodies in childhood. $\mathrm{Br}$ Med J 1971; iv: 469-72.

2 Baraka A, Bikhazi G. Oesophageal foreign bodies. Br Med J 1975; i: 561-3.

3 Levick R K, Spitz L, Robinson A. The 'invisible' can top. Br J Radiol 1977; 50: 594-6.

4 Burrington J D. Aluminium 'pop tops'. A hazard to child health. JAMA 1976; 235 : 2614-7.

Correspondence to Professor L Spitz, The Hospital for Sick Children, Great Ormond Street, London WCIN 3JH.

Received 23 February 1982

\title{
Serum pancreatic lipase as a screening test for cystic fibrosis
}

\author{
KAREL ADRIAENSSENS AND LODE VAN RIEL
}

Provincial Institute for Hygiene, Antwerp, Belgium

SUMMARY Pancreatic lipase catalyses the hydrolysis of emulsified triglycerides to form a transparent solution of monoglycerides and fatty acids. Levels of serum pancreatic lipase were measured in neonates known to have cystic fibrosis and compared with levels in control infants. During the first weeks of life infants with cystic fibrosis had raised serum pancreatic lipase values in parallel with raised serum trypsin values. A simple and specific turbidimetric dried blood spot assay for serum pancreatic lipase was used as a screening test for cystic fibrosis in the neonate.

It has been reported that the presence of a raised immunoreactive trypsin value in a dried blood spot is a useful screening test for neonates with cystic fibrosis (CF). ${ }^{1-3}$

Since pancreatic lipase activity parallels that of pancreatic trypsin during intrauterine and postnatal development ${ }^{4}$ (as it does in a variety of pancreatic disorders 5 ), the serum pancreatic lipase values in neonates with CF may be important. We studied the blood pancreatic lipase values during the first few weeks of life of neonates known to have CF and compared them with controls, and from this a simple screening test on dried blood spots was developed.

\section{Patients and controls}

Between September 1979 and May 1981, 7 neonates with CF were identified out of 26705 prospectively screened using the two-tier immunoreactive trypsin test. ${ }^{13} \mathrm{CF}$ was confirmed in these 7 infants by at least two abnormal sweat tests. Each had clinical symptoms of CF and was receiving treatment. Twenty dried blood samples had been collected from these 7 infants when aged between 5 days and 9 months, and these were available for a retrospective pancreatic lipase assay. Dried blood samples, each from the same batch as the CF sample, were used as controls, but the lipase values from the older Guthrie cards were lower because they had been stored for longer.

\section{Method}

The turbidimetric serum pancreatic lipase (EC 3.1.1.3) assay, ${ }^{6}$ available as the lipase monotest (Boehringer-Mannheim), was adapted for dried blood spots. The lipase reagent was prepared as recommended by the manufacturer. Dried blood standards (lipase activity 0,60,120,240, and 480 $\mathrm{U} / \mathrm{l}$ serum) were prepared from appropriate dilutions of the kit serum standard with saline, and mixed with washed and packed red blood cells to a final haematocrit value of $50 \%$, or were added to dried blood spots containing no lipase (inactivated by heating ${ }^{7}$ ). To elute the lipase from the dried blood sample or standard, $1.5 \mathrm{ml}$ of cooled $\left(0^{\circ}-4^{\circ} \mathrm{C}\right)$ lipase reagent was added to a dried blood spot, $6 \mathrm{~mm}$ in diameter, and placed in a refrigerator overnight or for at least 3 hours. As the samples were small and there was 
ultraviolet interference to the haemoglobin, it was necessary to lengthen the preincubation time to 90 minutes and the incubation time to 5 hours (or even overnight). The temperature for both these was $37^{\circ} \mathrm{C}$. The decrease in turbidity was measured at a wavelength of 663 or 699 . The calibration curve of the standards was linear from zero to $450 \mathrm{U} / 1$ lipase activity after 5 hours of incubation. The dried blood spot assay was comparable with the results of the routine serum lipase assay $(n=17$, range $75-187.4$ $\mathrm{U} / \mathrm{l}$, mean (X) 122.35 U/1+-31.12 SD; mean (Y) $116 \cdot 12 \mathrm{U} / 1+-28.98 \mathrm{SD} ; \mathrm{r}=0.75 ; \mathrm{P}=<0.01)$.

It is possible after overnight incubation for the naked eye to detect samples with high lipase activities by the decreased turbidity in them compared with the standards.

\section{Results}

The values of the serum pancreatic lipase and immunoreactive trypsin of the 7 CF neonates are compared with those of the controls in the Table. At the time of the first blood sample, when the infants were between 5 and 9 days old, the lipase of the infants with CF was 1.36-4.77 (mean 2.60) and the trypsin $2.84-7.65$ (mean 4.56 ) times higher than in the corresponding mean levels of the controls. By the time the second blood sample was taken (when the infants were between 25 and 87 days old) the difference between CF infants and controls was even greater, the lipase and trypsin levels being respectively $1 \cdot 41-6 \cdot 25$ (mean $3 \cdot 27$ ) and
5.23-15.95 (mean 9.74) times higher than the corresponding mean levels of the controls.

Case 6 was the only CF neonate in whom lipase activity during the first weeks of life was within the control range, and the lipase and trypsin levels declined in parallel to the control levels present at age 46 days.

\section{Discussion}

This study confirms previous observations that serun immunoreactive trypsin levels are raised during the first weeks of life in CF patients, and furthermore that levels of serum pancreatic lipase are similarly raised. In Case 6 there was a rapid reduction in the mass of functioning exocrine pancreatic cells due to the fact that this infant was small for gestational age 4 or owing to severity of the CF disease process itself, or perhaps to a combination of both factors. Indeed, in this patient, a clear diagnosis of severe exocrine pancreatic insufficiency was proved by the pathological results of the duodenal intubation following a pancreozymin-secretin test performed during the first month of life.

A variety of raised serum pancreatic proteins-for example trypsin, ${ }^{1}$ chymotrypsin, ${ }^{8}$ pancreatic secretory trypsin inhibitor, ${ }^{8}$ and now lipase are available as potential parameters for CF neonatal screening tests. The usefulness of this pancreatic lipase test, which requires no radioimmunoassay equipment, should be examined further in a more extensive prospective study.

Table Lipase and trypsin levels in infants with cystic fibrosis compared with controls

\begin{tabular}{|c|c|c|c|c|c|c|c|c|c|c|c|c|}
\hline \multirow[t]{3}{*}{ Case } & \multirow{3}{*}{$\begin{array}{l}\text { Birthweight } \\
(g)\end{array}$} & \multirow[t]{3}{*}{ Days after birth } & \multicolumn{5}{|c|}{ Lipase $(U / l$ serum $)$} & \multicolumn{5}{|c|}{ Trypsin $(\mu g / l$ serum $)$} \\
\hline & & & \multirow[t]{2}{*}{$C F$} & \multicolumn{3}{|c|}{ Control } & \multirow{2}{*}{$\begin{array}{l}\text { Ratio } \\
\text { CF : } \\
\text { control }\end{array}$} & \multirow[t]{2}{*}{$C F$} & \multicolumn{3}{|c|}{ Control } & \multirow{2}{*}{$\begin{array}{l}\text { Ratio } \\
\text { CF : } \\
\text { control }\end{array}$} \\
\hline & & & & Mean & Range & No & & & Mean & Range & No & \\
\hline \multirow[t]{3}{*}{$1^{*}$} & 3070 & 5 & 130 & 48 & $25-60$ & 10 & $2 \cdot 70$ & 1442 & 384 & $164-894$ & 10 & $3 \cdot 75$ \\
\hline & & 40 & 77 & 27 & $8-48$ & 3 & $2 \cdot 85$ & 2281 & 143 & $130-156$ & 3 & 15.95 \\
\hline & & 270 & 73 & 28 & $24-31$ & 4 & $2 \cdot 61$ & 958 & 200 & $130-288$ & 4 & $4 \cdot 79$ \\
\hline \multirow[t]{2}{*}{2} & 3900 & 6 & 113 & 35 & $18-53$ & 10 & $3 \cdot 23$ & 1492 & 407 & $275-664$ & 10 & 3.66 \\
\hline & & 56 & 150 & 24 & $12-36$ & 3 & $6 \cdot 25$ & 1925 & 170 & $82-278$ & 3 & $11 \cdot 32$ \\
\hline \multirow[t]{2}{*}{$3^{*}$} & 3600 & 5 & 83 & 44 & $14-64$ & 10 & $1 \cdot 88$ & 1694 & 391 & $236-578$ & 10 & $4 \cdot 33$ \\
\hline & & 33 & 73 & 32 & $16-45$ & 4 & $2 \cdot 28$ & 3039 & 216 & $135-341$ & 4 & 14.06 \\
\hline \multirow[t]{2}{*}{4} & 2650 & 6 & 103 & 44 & $14-64$ & 10 & $2 \cdot 34$ & 1833 & 391 & $236-578$ & 10 & 4.68 \\
\hline & & 87 & 87 & 26 & $16-36$ & 2 & $3 \cdot 34$ & 1248 & 164 & $100-227$ & 2 & $7 \cdot 60$ \\
\hline \multirow[t]{4}{*}{5} & 3250 & $\begin{array}{r}9 \\
55\end{array}$ & $\begin{array}{r}93 \\
130\end{array}$ & 47 & $26-74$ & 10 & $\begin{array}{l}1 \cdot 97 \\
2 \cdot 82\end{array}$ & $\begin{array}{l}1310 \\
1550\end{array}$ & 260 & $100-587$ & 10 & $\begin{array}{l}5.03 \\
7.78\end{array}$ \\
\hline & & 65 & 157 & 46 & $36-67$ & 4 & 3.41 & $2303\}$ & 199 & $100-486$ & 4 & 11.57 \\
\hline & & 77 & 110 & & & & $2 \cdot 39$ & 2000 & & & & 10.05 \\
\hline & & 111 & 140 & 55 & $54-63$ & 3 & $2 \cdot 54$ & 1324 & 152 & $100-255$ & 3 & $8 \cdot 71$ \\
\hline \multirow[t]{3}{*}{6} & 2350 & 5 & 67 & 49 & $32-71$ & 10 & $1 \cdot 36$ & 1469 & 516 & $337-821$ & 10 & $2 \cdot 84$ \\
\hline & & 25 & 88 & 62 & $48-75$ & 3 & 1.41 & 1025 & 164 & $100-255$ & 3 & $6 \cdot 25$ \\
\hline & & $\begin{array}{l}46 \\
60\end{array}$ & $\begin{array}{l}45 \\
29\end{array}$ & 37 & $20-54$ & 2 & $\begin{array}{l}1.21 \\
0.78\end{array}$ & $285\}$ & 150 & $100-201$ & 2 & $1 \cdot 73$ \\
\hline 7 & 3300 & $\begin{array}{r}60 \\
9\end{array}$ & $\begin{array}{r}29 \\
353\end{array}$ & 74 & $53-97$ & 10 & $\begin{array}{l}0 \cdot 78 \\
4 \cdot 77\end{array}$ & 1700 & 222 & 89-357 & 10 & $\begin{array}{l}1 \cdot 34 \\
7 \cdot 65\end{array}$ \\
\hline & & 83 & 170 & 43 & $19-57$ & 7 & 3.95 & 1465 & 280 & $200-469$ & 7 & $5 \cdot 23$ \\
\hline
\end{tabular}

- Boys. 
We thank Dr E Tritsmans for encouragement, the paediatricians for access to clinical data, and $\mathrm{R}$ Daenen for administrative assistance.

The Provincial Government of Antwerp provided financial support.

\section{References}

1 Crossley J R, Elliott R B, Smith P A. Dried-blood spot screening for cystic fibrosis in the newborn. Lancet 1979; i: $472-4$.

2 Crossley J R, Smith P A, Edgar B W, Gluckman P D, Elliott R B. Neonatal screening for cystic fibrosis using immunoreactive trypsin assay in dried-blood spots. Clin Chim Acta 1981;113: 111-21.

3 Adriaenssens K, Janssens H, Van Soom H. Letter: Two tier screen for cystic fibrosis. Lancet $1981 ; \mathrm{i}: 833$.

4 Lebenthal E. Pancreatic function and disease in infancy and childhood. Adv Pediatr 1978; 25: 223-61.
5 Otte M, Ehrardt F, Londong W, Forell M M. Immunoreactive trypsin-correlation studies to serum lipase and to trypsin in duodenal juice (abstract). Dan Med Bull 1979; 26: Supplement 1, 28.

- Neumann U, Ziegenhorn J. Determination of serum lipase with automated systems. In: Comptes-rendus du $4 e$ Colloque de Pont-à-Mousson 1978. Biologie prospective. Paris: Masson, 1979: 627-34.

7 Ziegenhorn J, Neumann U, Knitsch K W, Zwez W, Roeder A, Lenz H. Lipase-eine Testcharakteristik. Medica (Stuttgart) 1980; 11 : 1-5.

8 Borgström A, Sveger T, Lindberg T, Kullander S, Svanberg L. Immunoreactive trypsin, chymotrypsin, and pancreatic secretory trypsin inhibitor in cord blood from infants with cystic fibrosis. Acta Paediatr Scand 1981; 70: 619-21.

Correspondence to Dr K Adriaenssens, Provincial Institute for Hygiene, Nationalestraat 155, 2000 Antwerp, Belgium.

Received 12 January 1982

\title{
Effect of posture on gastro-oesophageal reflux in the newborn
}

\author{
I BLUMENTHAL AND G T LEALMAN
}

Department of Paediatrics, Bradford Royal Infirmary Maternity Unit, Bradford

SUMMARY The effect of posture on gastrooesophageal reflux was studied by giving 72 orogastric tube feeds to 18 low birthweight babies. Each infant was studied in each of 4 positions: prone, supine, right, and left lateral. Brilliant blue was added to feeds and reflux was determined by staining of a cotton thread opposite the holes in a feeding tube passing from the nose to the distal oesophagus. A comparison of the prone and supine positions showed that significantly less reflux occurred in the prone position.

The optimum position in which to nurse neonates is controversial, the position adopted by most nurseries being based more on custom than reason. It is well known that regurgitation of gastric contents can result in aspiration pneumonia and death in the newborn. Recently gastro-oesophageal reflux has been incriminated as a cause of apnoea and respiratory distress in the newborn and of 'near miss' and sudden death in infants. ${ }^{1}$ Prompted by such hazards the aim of the study was to determine the position associated with least reflux so that a rational choice for nursing infants in our nursery could be made.

\section{Patients and methods}

Eighteen healthy low birthweight infants were studied between the 2nd and 31st (mean 10) days. Mean ( \pm SE) birthweight was $1.78 \pm 0.07$ (range $1 \cdot 25-2.40) \mathrm{kg}$, and gestation $34.4 \pm 0.4$ (range 31-37) weeks. As the infants were preterm, all of them required some tube feeds, and informed parental consent was obtained. Approval for the study was obtained from the ethical committee of the Bradford District Hospitals.

The length of each infant was measured with a neonatometer and the distance from the nares to the distal oesophagus determined by the formula:

oesophageal length $(\mathrm{cm})=5+(0.252 \times$ infant length). ${ }^{2}$

A 6 FG polyvinyl feeding tube containing white crôchet cotton was passed through the nose so that the distal end was calculated to lie just above the stomach. The feeding tube which contained 6 small holes at $2.5 \mathrm{~cm}$ intervals along its length was firmly fixed to the face. The infant was placed in the designated position (prone, supine, left, or right lateral) and allowed to settle for a few minutes. A milk feed containing brilliant blue in sufficient quantity to impart a deep blue colour was then 